\title{
Virtual Tour Actual Usage: The Influence of Perceived Benefits and Sacrifices
}

\author{
Azzahra Putri Ramadhanty \\ Faculty of Computer Science \\ Universitas Indonesia \\ Azzahra.putri@ui.ac.id \\ Ave Adriana Pinem \\ Faculty of Computer Science \\ Universitas Indonesia \\ ave.pinem@cs.ui.ac.id
}

\author{
Putu Wuri Handayani* \\ Faculty of Computer Science \\ Universitas Indonesia \\ putu.wuri@cs.ui.ac.id
}

\author{
Muhammad Hafizhuddin Hilman \\ Faculty of Engineering \& IT \\ The University of Melbourne \\ muhammad.hilman@unimelb.edu.au
}

\begin{abstract}
Virtual tours are developed as alternatives to traditional tourism in Indonesia. This quantitative study analyzed factors that influence actual virtual tour usage. We modified the value-based adoption model to measure consumers' desire to adopt virtual tour services. A survey was conducted with 1,125 respondents who were aware of virtual tour services. The data were processed using covariance-based structural equation modeling. The results indicate that perceived benefits and sacrifices influenced behavioral intention to use these services. However, accessibility did not affect this intention. Behavioral intention to use significantly affected actual virtual tour usage. This research can help virtual tour providers and regulators increase service utilization and implementation.
\end{abstract}

Keywords: tourism, virtual tour, virtual reality, actual usage, Indonesia

\section{Introduction}

The tourism industry is crucial to the economic growth of a country like Indonesia, and it can provide benefits such as increased employment, foreign exchange, income, and tax revenues (Skanavis and Maria 2011). Because the tourism sector can support world economic growth, many countries have started to create policies and innovations to further develop their tourism industries (Skanavis and Maria 2011). Furthermore, Sabri (2020) demonstrated that while both pleasure and happiness are sources of health, happiness can be obtained through travel activities.

More technologies are being created to provide convenience and solutions for individuals and businesspeople in the tourism sector, and virtual tour services are one breakthrough success. Virtual tours present a series of videos or still images that may be supported by multimedia elements such as sound effects, music, narration, and text. Several countries have used virtual tour applications for more than a decade to attract tourists. More specifically, they have maintained websites that contain $360^{\circ}$ panoramic photos or videos of tourist destinations (Vishwakarma et al. 2020). As a promotional medium, virtual tours

\footnotetext{
* Corresponding Author
} 
are said to provide richer experiences and information than traditional brochures, catalogs, and websites (Vishwakarma et al. 2020).

In Indonesia, the development of virtual tour services is booming, especially during the COVID-19 pandemic (Kemenparekraf 2021). A state policy prevents people from traveling both domestically and internationally, with the aim of reducing transmissions of the COVID-19 virus. Notably, the pandemic has strongly impacted the tourism sector in Indonesia. Data from the Data Center and Infomation System revealed an $88.08 \%$ decrease in the number of foreign tourist arrivals (Kemenparekraf 2021). There were $1,377,067$ visits in December 2019, and this drastically decreased to 164,088 visits in December 2020 (Kemenparekraf 2021).

Traveloka, the leading online travel company in Indonesia, collaborated with the Ministry of Tourism and Creative Economy/Tourism and the Creative Economy Agency (Kemenparekraf) to launch the Online Xperience service, which is a virtual tour innovation (Antara 2020). Moreover, Kemenparekraf also collaborates with other travel platforms to introduce free virtual tours to Indonesians (Antara 2020). While virtual tours provide solutions to Indonesians who want to travel during the pandemic, they also allow businesspeople to keep their tourism businesses active (Mutiah 2020). However, virtual tours in Indonesia are still developing and being actively presented to Indonesians by those in the tourism sector (Mutiah 2020).

Until now, there was a lack of concrete data regarding virtual tour service usage in Indonesia. Vishwakarma et al. (2020) investigated the adoption of virtual reality (VR) devices for tourism by measuring the benefits and sacrifices incurred by Indian tourists when exploring tourist destinations virtually. In addition, Disztinger et al. (2017) analyzed user acceptance of VR devices to plan tourism. The use of VR devices has also increased in many countries in the gaming, health, and human resources sectors. However, the use of VR devices in Indonesia is limited due to factors such as their cost, which is still quite high. Because of the limited use of VR devices for virtual tours in Indonesia, this study differs from previous studies that focused on virtual tours supported by VR devices (e.g., Disztinger et al. 2017; Vishwakarma et al. 2020). Instead, this study covers virtual tour services on websites containing $360^{\circ}$ panoramic photos, and it prioritizes the $360^{\circ}$ virtual tour and live video virtual tour services available on online travel applications in Indonesia, such as those hosted by Traveloka and Airbnb.

Moreover, Disztinger et al. (2017) tested the use of VR devices on respondents with just one virtual tour application, Google Street View. However, this application is part of Google Maps and thus focuses more on navigational objectives than virtual tours. In contrast, this study analyzes multiple applications developed for virtual tour purposes. Finally, this study enriches the results of Caber et al. (2020), as the researchers did not account for the different perceptions and behaviors of first-time and repeat tourists. This study measures these differences in the context of tourists as users of virtual tour services.

This study applies the value-based adoption model (VAM) to measure consumers' desire to adopt virtual tour services based on their determined values (i.e., perceived values), which account for the benefits and sacrifices that they perceive. Lau et al. (2019) stated that the VAM can effectively measure technology adoption because it considers the perceived value of an individual. The VAM also pays more attention to perceived benefits and sacrifices than other technology adoption models, including the technology acceptance model, which only assesses what users obtain (Lau et al. 2019). This study contributes to the literature by analyzing the factors that influence a user's intention to adopt virtual tour services in Indonesia. Notably, this study can be used as a reference for service providers to evaluate their development of virtual tour services.

\section{Literature Review}

\section{Virtual Tour}

According to Ankomah and Larson (2018), virtual tours are information communication and technologybased tools that enable users to immerse themselves in and interact with virtual content from tourist destinations. These environments may be created with visual graphics, sound, and other multimedia elements (Ankomah and Larson 2018). Likewise, Umafagur et al. (2016) defined virtual tours as 
simulations of tourist attractions that are usually based on video or still images, with support from multimedia elements like sound effects, music, narration, and text.

A $360^{\circ}$ virtual tour is presented with photos or videos that users can rotate $360^{\circ}$ (Wulur et al. 2015). Various software programs can be used as a medium for VR photography techniques, immersive photography, or $360^{\circ}$ photos to display borderless and seamless images of tourist destinations that users can rotate $360^{\circ}$ (Wulur et al. 2015). Vishwakarma et al. (2020) defined VR as a simulated environment that is created in such a way that users feel as if they are really present in it (Vishwakarma et al. 2020).

A live video virtual tour utilizes streaming technology, which allows for video, audio, and other multimedia elements to be enjoyed in real time on different types of networks (Diwi et al. 2015). Streaming technology reduces file sizes by dividing the data into small packets to be sent over the Internet to end-user devices (e.g., mobile phones and laptops). Live video virtual tours generally take advantage of video conferencing applications to connect virtual tourists with tour guides.

\section{Value-based Adoption Model}

The VAM was first introduced by Kim et al. (2007), and it can effectively measure individual behavior related to technology adoption in the fields of online shopping, tourism, and hospitality (Vishwakarma 2020). The VAM measures perceived value from the perspective of a consumer by considering the benefits and sacrifices that they feel when using a technology (Vishwakarma 2020). Benefits refer to the "get" factor, which describes the specific benefits that consumers get from using a technology (Kim et al. 2007). In contrast, sacrifices are related to the "give" factor, which covers the sacrifices made by consumers to use a certain technology (Kim et al. 2007). Based on their perspectives on what they may gain and spend by using certain technologies, consumers make an overall assessment of a technology to determine their adoption intention (Kim et al. 2007).

\section{Research Hypothesis}

Perceived enjoyment is an intrinsic motivation factor, and the enjoyment that users feel comes from a sense of joy and joy from interaction with the system (Vishwakarma et al. 2020). Kim et al. (2007) proved that perceived enjoyment benefits consumers in the context of mobile Internet adoption. Furthermore, Hsu and Lin (2016) demonstrated that perceived enjoyment significantly affects technology acceptance. In the tourism field, it is assumed that virtually exploring a tourist destination will give users pleasure because these services provide them with unique and new experiences (Vishwakarma et al. 2020). Several breakthroughs in virtual tours have been made in Indonesia, especially during this pandemic. These tours aimed to provide pleasure for COVID-19 patients and healthy communities alike.

Evidently, perceived enjoyment is a factor that supports virtual tour acceptance, as it is important for a funoriented system to provide pleasure to its users (Van der Heijden 2004). The acceptance of the technology itself is referred to as behavioral intention to use, and this intention reflects the tendency of individuals to continue using a given technology (Davis 1989). Therefore, we propose the following hypothesis:

\section{H1: Perceived enjoyment (PENJ) has a significant influence on behavioral intention to use (BIU).}

Accessibility refers to how affordable and easy a technology is to obtain (Disztinger et al. 2017). When discussing accessibility on the web, Ballantyne et al. (2018) outlined four accessibility criteria, namely that the content should be perceivable, operable, understandable, and robust. Kulkarni (2018) emphasized that website accessibility is crucial for individuals to access information and participate in the fields of education, economics, and politics, which benefits all groups of people. In addition, accessibility is an important characteristic of online products that seek to provide broad access for all users, regardless of their physical, intellectual, or cognitive deficiencies (Leite 2021).

In the context of tourism, virtual tours in Indonesia have been intensively developed to support sustainable tourism by applying the principles of attraction, amenity, ancillary, and accessibility. Cheong (1995) 
reported that access to virtual tour services has a positive effect on travel-planning tourists, given that they receive richer information and real experiences by virtually visiting the tourist attractions that they intend to visit later on. In addition, Karahanna and Limayem (2000) classified accessibility into two types: physical accessibility and information accessibility. Significantly, user acceptance of a technology can be negatively affected by limited access to information and the physical use of this technology. Thus, we propose the following hypothesis:

\section{H2: Accessibility (ACC) has a significant influence on BIU.}

Epistemic value refers to the benefits felt by users when they use a product (Sheth et al. 1991). Further, epistemic value is part of the theory of consumption, and it explains the influences that determine consumer decisions to choose and buy a product (Sheth et al. 2019). Phau et al. (2014) stated that visitors receive epistemic value if they have new or different experiences during their visit. Focusing on virtual tour services, Vishwakarma et al. (2020) asserted that virtual tour service providers should target tourists who are fond of looking for new things (i.e., novelty) and interested in exploring new tourist attractions. Tourists with these characteristics are assumed to have an adventurous spirit and will tolerate the risks they face when using virtual tour services (Vishwakarma et al. 2020). With these characteristics, tourists can easily obtain epistemic value from their experiences with virtual tour services (Caber et al. 2020). Virtual tours are a new challenge for Indonesian tourism because of their hybrid concept, which combines virtual ideas and technology to attract tourists. Overall, virtual tour services can provide new experiences to tourists. Therefore, we present the following hypothesis:

\section{H3: Epistemic value (EV) has a significant influence on BIU.}

Technicality is an aspect of technology concerned with good performance while providing services (Kim et al. 2007). Moreover, it represents perceived ease of use, which refers to the extent to which an individual believes that the use of a system or technology does not require a lot of physical and mental effort (Kim et al. 2007). When conducting an ease-of-use assessment, users tend to ignore the external environment and instead focus on its interactions with the system (Kim et al. 2007). Kim et al. (2007) investigated how the ease-of-use component affects the adoption of mobile Internet technology. In doing so, they acknowledged that mobile Internet could only be run on limited devices in many cases, such as for owners of mobile phones with small screens that required high physical and mental effort to be interacted with. In the context of tourism, Schiopu et al. (2021) investigated VR reception of virtual tours during the current pandemic. Because they proved that perceived ease of use can strongly support the acceptance of VR technology, they recommended that VR tour service providers should improve VR performance in terms of its ease of use. Similarly, several virtual tour applications in Indonesia have made it easy for tourists to participate in virtual tourism activities. One technique utilizes video conferencing applications, such as Zoom, as a medium of interaction (Abu 2020).

Given that users assess the physical and mental effort spent using a given technology as an incurred cost, they view technicality as a non-monetary sacrifice (Kim et al. 2007). In addition, Kim et al. (2007) also emphasized that high technical complexity can have a significant negative relationship with technology acceptance. Consequently, we propose the following hypothesis:

\section{H4: Technicality (TECH) has a significant influence on BIU.}

As part of the theory of consumption, functional value considers the aspects that determine consumer decisions to choose and buy a product (Sheth et al. 1991). Functional value is assumed to be the main factor influencing a consumer's choice to buy a product, and it is based on economic utility theory, which explains individual preferences when making a choice (Sheth et al. 1991). This assumption is made because functional value involves aspects of product functionality, such as price and product quality, and is thus classified as a cost or monetary sacrifice that consumers must pay (Sheth et al. 1991).

In the context of tourism, functional value highlights the importance of the quality of the attractions and activities that tourists can interact with at affordable prices (Caber et al. 2020). The introduction of virtual tours in Indonesia has been actively carried out with the support of the Ministry of Tourism and Kemenparekraf, and its sponsored virtual tour program presents various tourist destinations free of charge. Significantly, Vishwakarma et al. (2020) included price as one sacrifice that users consider when accepting virtual tour services that use VR devices. 
This aspect is illustrated in the perceived cost variable, which presumably has a negative impact on technology adoption (Vishwakarma et al. 2020). The higher the costs that consumers incur to use a technology, the lower their willingness to adopt it (Vishwakarma et al. 2020). While Vishwakarma et al. (2020) did not analyze the quality of the virtual tour service in their research model, they suggested that future research in this field should consider quality. Thus, we formed the following hypothesis:

\section{H5: Functional value (FV) has a significant influence on BIU.}

Interest is a psychological condition in which an individual tends to re-engage with something from time to time (Hidi and Renninger 2006). In addition, interest has a relationship with curiosity and engagement. An individual's interest in and engagement with something can arise if they are curious about it (Arnone et al. 2011). Interest can also retrigger curiosity, and if this interest is maintained, it will create a maintained situational interest (Arnone et al. 2011). Consequently, an individual's interest in a technology arises because of their initial curiosity about it, and it has also been proven that interest has a positive relationship with behavioral intention to use (Disztinger et al. 2017). Moreover, several previous studies have demonstrated that an individual's interest in following technological developments significantly influences their behavioral intention to adopt a technology (Schiopu et al. 2021). For example, Sanchez-Cabrero et al. (2019) reported that an individual's interest in technology can support their desire to use VR technology as a learning tool for educational purposes.

In the context of tourism, many Indonesians are becoming interested in using virtual tour services specifically during the pandemic. Roughly 900 virtual tourists explored domestic tourist destinations from July to September 2020 (Kemenparekraf 2021). Disztinger et al. (2017) claimed that an individual's interest positively influences their desire to adopt VR tour technology for the benefit of travel planning. Beck et al. (2019) also proved that an individual's interest in VR technology can specifically influence their behavioral intentions to adopt virtual tour activities that are supported by VR devices. Likewise, Beck et al. (2019) emphasized that it is important for tourism managers and marketers to investigate whether their target market is interested in VR technology. Therefore, we created the following hypothesis:

\section{H6: Interest (INT) has a significant effect on BIU.}

Actual usage is defined as the actual behavior or conditions of using a system, and it is significantly influenced by behavioral intention to use (Davis 1989). Amelia and Ronald (2017) proposed that behavioral intention to use can determine the actual usage of a technology. Furthermore, Paluri and Mehra (2015) found the same relationship between behavioral intention to use and actual usage in the acceptance of a technology. In the context of technology acceptance, most tourism research still does not focus on technology actual usage. Following these references, we present the following hypothesis:

H7: BIU has a significant influence on virtual tour actual usage (AU).

\section{Methodology}

\section{Data Collection and Analysis}

This quantitative study used online questionnaires to collect its data. After we designed the questionnaire, we carried out a readability test to test its feasibility and determine how well a prospective respondent would understand its questions. We conducted the readability test by distributing questionnaires to seven respondents with different demographic backgrounds. Most feedback noted that our vocabulary was not standardized, which made the questionnaire uncomfortable to read. In response, we revised the questionnaire and then distributed a link to it on various social media platforms, including Instagram, LINE, Twitter, and WhatsApp.

The data were collected online to reach more respondents, especially those with a broad demographic background. Regarding our respondent sampling technique, we used purposive sampling, which determines the sample by categorizing the respondents in accordance with the context of the study. We targeted Indonesian respondents who were aware or had knowledge of virtual tour services, especially those who had used these services. 


\section{Model}

We designed our research model by modifying the VAM and considering the insights of Vishwakarma et al. (2020), Disztinger et al. (2017), and Caber et al. (2020). We selected the variables that were most appropriate for our context and hypotheses. As shown in Figure 1, our research model had eight variables, consisting of seven exogenous variables and one endogenous variable.

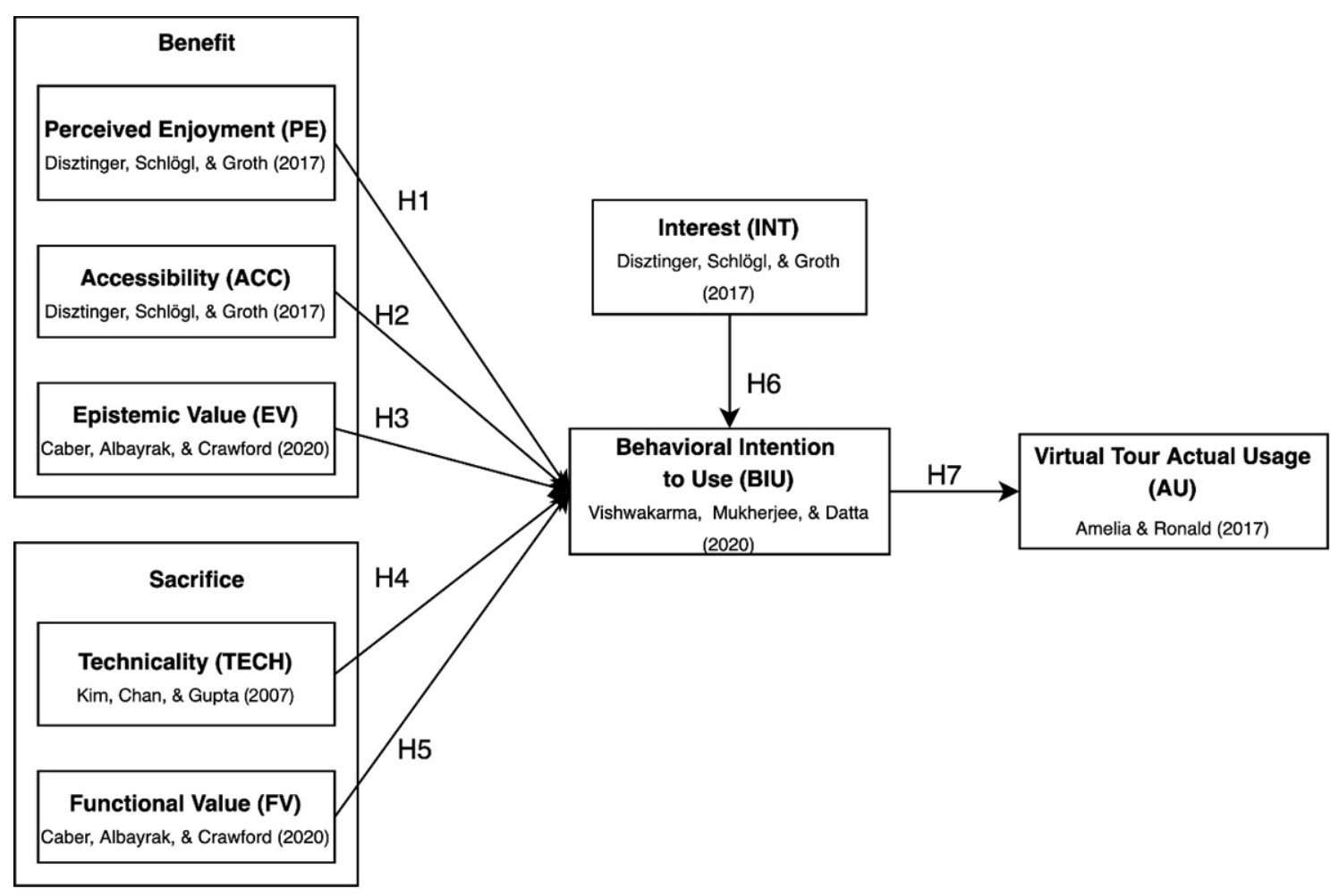

Figure 1. The Proposed Model

\section{Analysis}

We used covariance-based structural equation modeling to process and analyze the data, and our tools were SPSS, Amos 24, and Microsoft Excel. Our data analysis had six main steps: specifying the research model, identifying the research model, estimating the research model, testing the feasibility of the research model, modifying the research model, and hypothesis testing.

\section{Instruments}

Our questionnaire was divided into four parts. The first part contained validation questions to determine whether each respondent had used a virtual tour service before. If not, then the respondent could access examples of virtual tour services. The second part contained questions related to the demographics of the respondents, and it collected information such as their email address or cellphone number, gender, age, domicile, latest or current education level, current job, and monthly income. The third section contained questions related to the research instruments and characteristics of using virtual tour services. To address the research instrument, this section used 33 questions with a five-point Likert scale, ranging from strongly disagreed (1) to strongly agreed (5) (see Appendix A). The final section included questions related to the respondents' demographics and experiences while using virtual tour services. 


\section{Result}

\section{Respondent Demographics}

The survey was distributed from February 19 to March 19, 2021. We obtained a total of 1,922 responses. Of the total respondents, only 1,125 respondents completely filled out the survey. Hence, other 797 respondents did not provide complete data; thus, we eliminate those data. Table 1 displays the demographics of the respondents.

Table 1. The Respondents' Demographics

\begin{tabular}{|c|c|c|c|}
\hline \multicolumn{2}{|c|}{ Demographics } & Percentage (\%) & Number of \\
\hline \multirow[t]{2}{*}{ Have used a virtual tour } & Yes & 64.09 & 721 \\
\hline & No & 35.91 & 404 \\
\hline \multirow[t]{2}{*}{ Gender } & Male & 55.82 & 628 \\
\hline & Female & 44.18 & 497 \\
\hline \multirow[t]{4}{*}{ Age } & 16-25 years old & 90.93 & 1,023 \\
\hline & $26-35$ years old & 6.93 & 78 \\
\hline & $36-45$ years old & 0.53 & 6 \\
\hline & $>45$ years old & 1.60 & 18 \\
\hline \multirow{8}{*}{ Domicile } & Greater Jakarta & 57.87 & 651 \\
\hline & $\begin{array}{l}\text { Outside Greater Jakarta in Java } \\
\text { Island }\end{array}$ & 27.11 & 305 \\
\hline & Sumatera Island & 5.33 & 60 \\
\hline & Bali/NTT/NTB Island & 2.49 & 28 \\
\hline & Kalimantan Island & 2.84 & 32 \\
\hline & Sulawesi Island & 1.96 & 22 \\
\hline & Maluku/Papua Island & 0.09 & 1 \\
\hline & Other & 2.31 & 26 \\
\hline \multirow[t]{5}{*}{ Type of virtual tour used } & $360^{\circ}$ virtual tour & 64.62 & 727 \\
\hline & $\begin{array}{l}\text { Online experiences on } \\
\text { travelling apps }\end{array}$ & 38.22 & 430 \\
\hline & Virtual tour mobile apps & 11.47 & 129 \\
\hline & VR tour & 16.62 & 187 \\
\hline & Others & 4.18 & 47 \\
\hline
\end{tabular}

\section{Measurement Model Assessment}

We assessed the measurement model based on its convergent validity, discriminant validity, and internal consistency reliability (Hair et al. 2014). We carried out a convergent validity test by examining the loading factor value of each indicator. Each loading factor value needed to be $\geq 0.708$ (Hair et al. 2014). After the modification process, all indicators had loading factors $>0.7$. 
We conducted a reliability test by examining the Cronbach's alpha (CA) of each factor. Each CA required a value $\geq 0.7$ and next, we examined the construct reliability $(\mathrm{CR})$ value, with a recommended $C R$ value $\geq$ 0.7 (Hair et al. 2014). For the last step of the reliability test, we examined the average variance extracted (AVE). AVE is the average convergent indicator of the extracted variance for all items in construction (Hair et al. 2014). Our variables met the criteria: all CA values were $>0.7, \mathrm{CR}$ values were $>0.7$, and AVE values were > 0.5 (Table 2).

Table 1. Cronbach's Alpha (CA), Construct Reliability (CR), and Average Variance Extracted (AVE) Values

\begin{tabular}{|l|r|r|r|}
\hline \multicolumn{1}{|c|}{ Variable } & CA & \multicolumn{1}{c|}{ CR } & \multicolumn{1}{c|}{ AVE } \\
\hline PE & 0.893 & 0.898620373 & 0.6909915 \\
\hline ACC & 0.849 & 0.849139198 & 0.58492325 \\
\hline EV & 0.83 & 0.950115044 & 0.865131333 \\
\hline TECH & 0.828 & 0.805636274 & 0.580485333 \\
\hline FV & 0.894 & 0.89568604 & 0.6328888 \\
\hline BIU & 0.924 & 0.920520393 & 0.763507 \\
\hline INT & 0.839 & 0.901448414 & 0.753083667 \\
\hline AU & 0.799 & 0.933996394 & 0.828149667 \\
\hline
\end{tabular}

We used a discriminant validity test to ensure that each construct was considered to be unique compared to the other constructs in the model (Hair et al. 2014). To complete the discriminant validity test, we compared the cross-loading values of each indicator. Each indicator needed to have a higher loading value for the measured variable than for the other variables. As shown in Table 3, the model passed the discriminant validity test and could therefore undergo the structural model test.

Table 3. Discriminant Validity Test Results

\begin{tabular}{|l|r|r|r|r|r|r|r|l|}
\hline & \multicolumn{1}{l|}{ INT } & \multicolumn{1}{l|}{ FV } & TECH & EV & \multicolumn{1}{l|}{ ACC } & PE & BIU & AU \\
\hline INT & 1 & & & & & & & \\
\hline FV & 0.437 & 1 & & & & & & \\
\hline TECH & 0.512 & 0.773 & 1 & & & & & \\
\hline EV & 0.367 & 0.57 & 0.593 & 1 & & & & \\
\hline ACC & 0.359 & 0.656 & 0.735 & 0.469 & 1 & & & \\
\hline PE & 0.383 & 0.629 & 0.6 & 0.522 & 0.48 & 1 & & \\
\hline BIU & 0.394 & 0.649 & 0.546 & 0.519 & 0.47 & 0.666 & 1 & \\
\hline AU & 0.152 & 0.25 & 0.21 & 0.2 & 0.181 & 0.256 & 0.385 & \\
\hline AU4 & 0.113 & 0.187 & 0.157 & 0.149 & 0.135 & 0.191 & 0.342 & 0.768 \\
\hline AU3 & 0.151 & 0.248 & 0.209 & 0.199 & 0.18 & 0.255 & 0.383 & 0.996 \\
\hline AU1 & 0.152 & 0.25 & 0.318 & 0.2 & 0.181 & 0.256 & 0.373 & 0.997 \\
\hline INT3 & 0.861 & 0.376 & 0.44 & 0.316 & 0.309 & 0.33 & 0.339 & 0.131 \\
\hline INT2 & 0.888 & 0.388 & 0.455 & 0.326 & 0.319 & 0.341 & 0.35 & 0.135 \\
\hline
\end{tabular}




\begin{tabular}{|l|r|r|r|r|r|r|r|r|}
\hline & \multicolumn{1}{l|}{ INT } & \multicolumn{1}{l|}{ FV } & \multicolumn{1}{l|}{ TECH } & \multicolumn{1}{l|}{ EV } & \multicolumn{1}{l|}{ ACC } & \multicolumn{1}{l|}{ PE } & \multicolumn{1}{l|}{ IIU } & \multicolumn{1}{l|}{ AU } \\
\hline INT1 & 0.854 & 0.373 & 0.437 & 0.314 & 0.306 & 0.327 & 0.337 & 0.13 \\
\hline BIU1 & 0.362 & 0.596 & 0.501 & 0.477 & 0.432 & 0.611 & 0.918 & 0.353 \\
\hline BIU2 & 0.371 & 0.611 & 0.514 & 0.489 & 0.443 & 0.627 & 0.941 & 0.362 \\
\hline BIU3 & 0.347 & 0.57 & 0.479 & 0.456 & 0.413 & 0.585 & 0.879 & 0.338 \\
\hline BIU4 & 0.367 & 0.604 & 0.508 & 0.484 & 0.438 & 0.62 & 0.722 & 0.278 \\
\hline FV1 & 0.326 & 0.747 & 0.577 & 0.426 & 0.49 & 0.544 & 0.514 & 0.198 \\
\hline FV2 & 0.316 & 0.722 & 0.558 & 0.412 & 0.474 & 0.454 & 0.469 & 0.18 \\
\hline FV3 & 0.356 & 0.816 & 0.63 & 0.465 & 0.535 & 0.513 & 0.529 & 0.204 \\
\hline FV4 & 0.336 & 0.77 & 0.595 & 0.439 & 0.505 & 0.484 & 0.499 & 0.192 \\
\hline FV5 & 0.342 & 0.783 & 0.605 & 0.446 & 0.513 & 0.492 & 0.508 & 0.195 \\
\hline TECH1 & 0.391 & 0.59 & 0.764 & 0.453 & 0.561 & 0.458 & 0.417 & 0.16 \\
\hline TECH2 & 0.394 & 0.596 & 0.771 & 0.457 & 0.566 & 0.463 & 0.421 & 0.162 \\
\hline TECH3 & 0.377 & 0.569 & 0.736 & 0.437 & 0.541 & 0.442 & 0.402 & 0.154 \\
\hline EV2 & 0.365 & 0.567 & 0.59 & 0.994 & 0.466 & 0.519 & 0.516 & 0.198 \\
\hline EV3 & 0.297 & 0.462 & 0.48 & 0.81 & 0.38 & 0.423 & 0.42 & 0.162 \\
\hline EV4 & 0.365 & 0.567 & 0.59 & 0.994 & 0.467 & 0.519 & 0.516 & 0.199 \\
\hline ACC4 & 0.288 & 0.527 & 0.591 & 0.377 & 0.804 & 0.386 & 0.378 & 0.145 \\
\hline ACC3 & 0.285 & 0.52 & 0.583 & 0.372 & 0.793 & 0.381 & 0.373 & 0.143 \\
\hline ACC2 & 0.265 & 0.484 & 0.543 & 0.347 & 0.739 & 0.294 & 0.323 & 0.124 \\
\hline ACC1 & 0.234 & 0.427 & 0.479 & 0.306 & 0.651 & 0.313 & 0.306 & 0.118 \\
\hline PE4 & 0.288 & 0.566 & 0.451 & 0.393 & 0.361 & 0.752 & 0.533 & 0.205 \\
\hline PE3 & 0.353 & 0.578 & 0.552 & 0.481 & 0.442 & 0.92 & 0.613 & 0.236 \\
\hline PE2 & 0.347 & 0.569 & 0.544 & 0.473 & 0.435 & 0.906 & 0.603 & 0.232 \\
\hline PE1 & 0.388 & 0.636 & 0.608 & 0.529 & 0.486 & 0.704 & 0.553 & 0.213 \\
\hline
\end{tabular}

\section{Structural Model Test}

After we properly measured the latent variables with a measurement model test, we needed to investigate the relationship between the latent variables with a structural model test (Schumacker and Lomax 2010). The structural model test evaluated several values against the goodness-of-fit (GoF) criterion, which determined how suitable the model was for the obtained data (Schumacker and Lomax 2010). We compared CMIN/df, RMSEA, NFI, CFI, GFI, TLI, and RMR with the GoF criterion. Table 4 contains the final GoF value, which we determined after modifying the model.

Table 4. Final GoF Results

\begin{tabular}{|l|c|c|c|}
\hline Index & Cut-off Value & Result & Value \\
\hline CMIN/df & $<2.0$ & 1.999 & good fit \\
\hline RMSEA & $<=0.08$ & 0.031 & good fit \\
\hline
\end{tabular}




\begin{tabular}{|l|c|c|c|}
\hline \multicolumn{1}{|c|}{ Index } & Cut-off Value & Result & Value \\
\hline NFI & $>=0.9$ & 0.97 & good fit \\
\hline CFI & $>=0.9$ & 0.985 & good fit \\
\hline GFI & $>=0.9$ & 0.959 & good fit \\
\hline TLI & $>=0.9$ & 0.981 & good fit \\
\hline RMR & $<=0.05$ & 0.046 & good fit \\
\hline
\end{tabular}

\section{Hypothesis Testing}

We carried out hypothesis testing using a two-way test (two-tailed) with a significance level of 5\%. Table 5 displays the results. We accepted a hypothesis if it had a p value $<0.05$ (Hair et al. 2014). From our total of seven hypotheses, we rejected only one hypothesis $(\mathrm{H} 2)$.

Table 2. Hypotheses Testing

\begin{tabular}{|l|l|l|l|r|r|l|}
\hline \multicolumn{3}{|c|}{ Hypothesis } & \multicolumn{1}{c|}{ Estimate } & \multicolumn{1}{c|}{ P } & Result \\
\hline H1 & BIU & $<---$ & PE & 0.39 & 0.002 & Accepted \\
\hline H2 & BIU & $<---$ & ACC & 0.02 & 0.653 & Rejected \\
\hline H3 & BIU & $<---$ & EV & 0.123 & 0.002 & Accepted \\
\hline H4 & BIU & $<---$ & TECH & -0.142 & 0.026 & Accepted \\
\hline H5 & BIU & $<---$ & FV & 0.403 & 0.003 & Accepted \\
\hline H6 & BIU & $<---$ & INT & 0.066 & 0.025 & Accepted \\
\hline H7 & AU & $<---$ & BIU & 0.345 & 0.002 & Accepted \\
\hline
\end{tabular}

\section{Discussion}

We find that the respondents had a higher desire to use virtual tour services if they felt joy or excitement while visiting virtual tourist attractions (H1). Our results reinforce those of Disztinger et al. (2017). They noted that when perceived enjoyment is treated as a hedonic system, it can have its strongest supportive effect on virtual tour acceptance. This hedonic system must be developed to provide self-fulfilling value to its users, and it is also important for the hedonic system to be oriented toward providing pleasure as well. Moreover, our results also support those of Vishwakarma et al. (2020) which were conducted in India. They reported that the virtual exploration of a tourist destination gives users pleasure because doing so provided them with uniqueness and new experiences. Further, Vishwakarma et al. also showed that perceived enjoyment is an important value that can influence individuals' desire to use virtual tour services.

Notably, we observed that accessibility did not significantly affect behavioral intention to use (H2). This is in accordance with Disztinger et al. (2017), as they also found that accessibility did not affect the behavioral intention to use virtual tour services for travel-planning purposes. To better understand this rejected hypothesis, we interviewed five respondents. All respondents said that in their own environments, many people did not know about the existence of virtual tour services. They thought that this was due to a lack of promotion or socialization from virtual tour developers that targeted Indonesians. In addition, some respondents theorized that people may have lacked information on how to access virtual tours because they were not interested in these services. For example, Respondent 3 stated, "There are not many services available, and I don't know where to access them. Maybe because I am not interested myself." Likewise, Respondent 5 claimed, "Not interested in virtual tours, so there is no intention to find out." Moreover, the 
respondents explained that because live video virtual tour services were sold on traveling applications, their high prices also reduced accessibility. Respondent 3 asserted, "If I have to pay, I don't think I am willing."

However, the interview results suggest that if individuals can access compatible devices and the Internet, then virtual tour services have the benefit of being accessible anytime and anywhere. In the words of Respondent 2, "This virtual tour service is not limited by space and time, [as] no there are opening or closing hours." Regardless, there were other important barriers to their use. Information related to the existence of virtual tour services may have struggled to reach various age groups. Respondent 4 stated, "Millennials and below may not be too affected because they are technology literate enough to adapt easily. However, the older generation is not necessarily [the same]." These services were not necessarily accessible to Indonesians in remote areas with poor Internet access and few compatible devices. Respondent 5 reported, "Many people in remote areas also do not have good enough devices and adequate Internet to access this virtual tour."

Based on our analysis, we conclude that a lack of awareness, Internet access, and infrastructure impedes local knowledge about virtual tour services and how to access them. We also propose that the limited spread of virtual tour services throughout Indonesian society has resulted in a low desire to use these services. Notably, $59.02 \%$ of the questionnaire respondents were hopeful about the future of virtual tour services, as they supported the increased promotion of these services to Indonesians. Interestingly, our results demonstrate that while the virtual tour services now offered in Indonesia are increasingly convenient, most respondents still encountered obstacles to their use. For instance, $63.82 \%$ of respondents had an unstable Internet connection, and $48.98 \%$ faced problems when using the features of the virtual tour service.

We also discovered that epistemic value significantly influenced behavioral intention to use (H3). In other words, the respondents had a desire to use virtual tour services if they could gain new experiences that would satisfy their curiosity and raise their enthusiasm for traveling. Hence, this study bolsters Caber et al. (2020), as they found that epistemic value is a significant value aspect. Crucially, epistemic value can affect users' desire to use virtual tour services (Vishwakarma et al. 2020). Further, our results support the theory of consumption, within which epistemic value helps to determine consumers' decisions to choose and buy a product (Sheth et al. 2019). Our results also strengthen those of Phau et al. (2014). They concluded that tourists gain epistemic value if they have new or different experiences because of their visit.

Also, we observed that technicality significantly impacted behavioral intention to use (H4). This suggests that the effort that a user spends to access virtual tour services can affect their desire to use them. We found that the facilities of Indonesian virtual tours performed well while offering their services to virtual tourists. Our results are in line with those of Schiopu et al. (2021). They reported that low system complexity plays a big role in supporting user acceptance of VR tour technology. Moreover, our study echoes Vishwakarma et al. (2020) and contradict Disztinger et al. (2017).

Furthermore, we noted that functional value significantly influenced behavioral intention to use (H5). More specifically, the respondents' desire to use virtual tour services was influenced by their quality and price. Thus, our results contradict those of Vishwakarma et al. (2020). They concluded that perceived cost, viewed as part of the functional value, is not a value aspect capable of determining an individual's desire to use a virtual tour. However, their study was conducted in India, where the price of VR devices is quite affordable and therefore accessible. Moreover, because Vishwakarma et al. (2020) did not examine service quality, our study enriches their results. This study also supports Caber et al. (2020). In the context of offline tourism, they determined that functional value is important for measuring the quality of attractions and activities that tourists seek out at commensurate prices.

We conclude that virtual tour services in Indonesia are sufficient to provide functional value because some of these services are free. $61.78 \%$ of our respondents reported that feature quality was quite satisfactory. On the other hand, our respondents still hoped for further development of virtual tour services, including $62.84 \%$ who wanted additional interactivity and $56.89 \%$ who desired more diverse tourist destinations.

Next, this study reported that interest significantly influenced behavioral intention to use (H6). In other words, the desire to use virtual tour services may arise if individuals are already interested in the technology. Our results support those of Disztinger et al. (2017). They proposed that an individual's interest in new technology, which can be fostered by following trends or technological developments, can significantly 
influence their desire to adopt virtual tours for travel-planning purposes. Notably, Disztinger et al. (2017) studied individuals who were already aware of virtual technology and even had personal VR glass devices, regardless of the fact that this technology was relatively new and considered to be "futuristic." These participants were also aware of the use of VR in virtual tours.

Moreover, our results on the subject of interest bolster those of Beck et al. (2019). They noticed that an individual's interest in VR technology can specifically influence their desire to adopt a VR tour, either for the sake of travel planning or personal satisfaction. Likewise, Beck et al. (2019) also demonstrated that, compared to other variables, general interest is the strongest predictor of or has the greatest influence on behavioral intention to use.

Virtual tour services continue to be actively developed and used in Indonesia. Recently, they have served as an alternative to normal tourism for Indonesians during the pandemic, and they are also expected to provide new experiences for virtual tourists (Kemenparekraf 2021). Consequently, this study demonstrates the ability of virtual tour services to provide new experiences to Indonesians and their alternative use during the pandemic. According to our data, $64.09 \%$ of respondents had previously used virtual tour services, including $360^{\circ}$ virtual tours and live video virtual tours. Of the various types of virtual tour services, $360^{\circ}$ virtual tours were the most popular among respondents. Significantly, our results support the theory of planned behavior proposed by Ajzen (1991). The theory states that behavioral intention can trigger consumer behaviors, including actual usage, in the future. These behaviors can apply to virtual tour services (Amelia and Ronald 2017).

\section{Implication}

The results validate our proposed VAM, which shows how users may adopt virtual tour services if they obtain certain values while virtually exploring a tourist destination. These values are divided into benefits and sacrifices, both of which affect the emergence of behavioral intention to use virtual tour services. This emergence is accompanied by a sense of interest from within the individual. Crucially, behavioral intention has a significant effect on actual virtual tour usage. Our results agree with those of Vishwakarma et al. (2020) which were conducted in India and Disztinger et al. (2017) which were conducted in Austria. In addition, our results support Caber et al. (2020) by proving that both functional and epistemic values are important benchmarks to determine an individual's perception of a tourism activity.

Our results may help developers maximize virtual tour implementation by outlining how they can provide value for virtual tourists. We recommend that developers intensify their socialization and promotion activities to increase the awareness of virtual tour services among Indonesians. They can do so with support from other parties in the tourism sector, especially regulators. These socialization and promotion activities may take advantage of digital platforms, such as social media, to reach the wider community.

Additionally, we recommend that virtual tour service developers improve the features available in their services. Based on our data, these services should be more interactive. For example, some respondents suggested the addition of a chat service that would allow them to communicate with other virtual visitors. Other requested a virtual tour guide with Artificial Intelligent technology to increase visitor interaction with the system.

We acknowledge that support from regulators in the tourism sector is necessary to help developers increase awareness of and public access to virtual tour services. While the government has already taken several measures, such as the Ministry of Tourism and Creative Economy offering a free virtual tour service, its efforts can be expanded further by offering more diverse tourist destinations. In addition, many Indonesians still face obstacles when trying to access and use virtual tour services. Hence, we propose that regulators should improve Internet quality in Indonesia. This will allow Indonesians to take full advantage of the services available on the Internet, not limited to virtual tours, and thus allow them to properly meet their needs. 


\section{Conclusion}

In this pandemic situation, virtual tours could provide solution for the tourism industry in Indonesia. However, few studies analyze the virtual tours actual usage. This study determined that perceived enjoyment, epistemic value, functional value, technicality, and interest significantly affected behavioral intention to use virtual tour services. In contrast, accessibility had no significant effect on behavioral intention. Following our results, developers in Indonesia should increase public access to and awareness of virtual tour services, with support from regulators in the tourism sector. Because this study only covered $360^{\circ}$ virtual tours and live video virtual tours, further research should test other types of virtual tour services, such as mobile application virtual tours and virtual tour services. In addition, future studies should focus on VR glass devices as VR technology continues to develop in Indonesia.

\section{References}

Abu. 2020. Virtual Tour dengan Aplikasi Zoom Bagaimana Caranya?. Pandu Asia. (https://www.panduasia.com/blog/virtual-tour-dengan-applikasi-zoom-bagaimana-caranya, accessed June 4, 2020).

Ajzen, I. 1991. "The theory of planned behavior," Organizational Behavior and Human Decision Processes (50:2), pp. 179-211.

Amelia, A., and Ronald, R. 2017. "The effect of technology acceptance model (TAM) toward actual usage through behavioral intention in real effort to increase Internet banking users in Indonesia," International Journal of Advanced Research (5), pp. 866-879.

Ankomah, P., and Larson, T. 2018. "Virtual tourism and its potential for tourism development in subSaharan Africa," In Khosrow-Pour, M. (Ed.), Encyclopedia of Information Science and Technology (4 ${ }^{\text {th }}$ ed., pp. 4113-4122). IGI Global.

Antara. 2020. "Kemenparekraf Dukung Inovasi Tur Virtual untuk Promosikan Pariwisata," Borneo News. (https://www.borneonews.co.id/berita/188073-kemenparekraf-dukung-inovasi-tur-virtual-untukpromosikan-pariwisata, accessed October 8, 2020 ).

Arnone, M. P., Small, R. V., Chauncey, S. A., and McKenna, H. P. 2011. "Curiosity, interest and engagement in technology-pervasive learning environments: A new research agenda," Educational Technology Research and Development (59:2), pp. 181-198.

Ballantyne, M., Jha, A., Jacobsen, A., Hawker, J., and El-Glaly, Y. 2018. "Study of accessibility guidelines of mobile applications," The 17th International Conference on Mobile and Ubiquitous Multimedia (MUM 2018) Proceedings (2018), pp. 305-315.

Beck, J., Rainoldi, M., Egger, R. 2019. "Virtual reality in tourism: a state-of-the-art review," Tourism Review (74:3), pp. 586-612. 10.1108/TR-03-2017-0049.

Caber, M., Albayrak, T., Crawford, D. 2020. "Perceived value and its impact on travel outcomes in youth tourism," Journal of Outdoor Recreation and Tourism (31), pp. 100327.

Cheong, R. 1995. "The virtual threat to travel and tourism," Tourism Management (16:6), pp. 417-422.

Davis, F. D. 1989. "Perceived usefulness, perceived ease of use, and user acceptance of information technology", MIS Quarterly (13:3), 319-340.

Disztinger, P., Schlögl, S., Groth, A. 2017. "Technology acceptance of virtual reality for travel planning," Information and Communication Technologies in Tourism 2017, pp. 255-268.

Diwi, A. I., Mangkudjaja, R. R., and Wahidah, I. 2015. "Analisis Kualitas layanan video live Streaming Pada jaringan Lokal Universitas Telkom," Buletin Pos Dan Telekomunikasi (12:3), pp. 207-216.

Hair, J. F., Black, W. C., Babin, B. J., and Anderson, R. E. 2014. Multivariate data analysis (MVDA). In Pearson New International Edition ( $7^{\text {th }}$ ed.). Pearson Education Limited.

Hidi, S., and Renninger, K. A. 2006. "The four-phase model of interest development," Educational Psychologist (41:2), pp. 111-127.

Hsu, C. and Lin, J. 2016, "An empirical examination of consumer adoption of Internet of Things services: Network externalities and concern for information privacy perspectives," Computers in Human Behavior 62, pp. 516-527.

Karahanna, E., and Limayem, M. 2000. "E-mail and V-mail usage: generalizing across technologies," Journal of Organizational Computing and Electronic Commerce (10:1), pp. 49-66. 
Kemenparekraf. 2021. "Statistik kunjungan Wisatawan Mancanegara 2020", Kemenparekraf. (https://www.kemenparekraf.go.id/statistik-wisatawan-mancanegara/Statistik-KunjunganWisatawan-Mancanegara-2020, accessed April 7, 2020)

Kim, H. W., Chan, H. C., and Gupta, S. 2007. "Value-based adoption of mobile Internet: an empirical investigation," Decision Support Systems (43:1), pp. 111-126.

Kulkarni, M. 2018. "Digital accessibility: challenges and opportunities," IIMB Management Review (31:1), pp. 91-98.

Lau, C., Chui, R., and Au, N. 2019. "Examination of the adoption of augmented reality: a VAM approach," Asia Pacific Journal of Tourism Research (24), pp. 1005-1020.

Leite, M., Scatalon, L., Freire, A., and Eler, M. 2021. "Accessibility in the mobile development industry in Brazil: Awareness, knowledge, adoption, motivations and barriers," Journal of Systems and Software (177), pp. 110942.

Mutiah, D. 2020. "Menabung Calon Turis Lewat Tur Wisata Virtual di Masa Pandemi," Liputan 6. (https://www.liputan6.com/lifestyle/read/4385933/menabung-calon-turis-lewat-tur-wisata-virtualdi-masa-pandemi, accessed October 19, 2020).

Paluri, R. and Mehra, S. 2015. "Exploring the acceptance for e-learning using technology acceptance model among university students in India," International Journal of Process Management and Benchmarking (5:2), pp. 194-210.

Phau, I., Quintal, V., and Shanka, T. 2014. "Examining a consumption values theory approach of young tourists toward destination choice intentions," International Journal of Culture, Tourism, and Hospitality Research (8:2), pp. 125-139.

Sabri, H. A. 2020. "Yuk Ciptakan Rasa Bahagia Meski Berwisata Virtual Lewat Indonesia.Travel $360^{\circ}$ Images. Bisnis Wisata," Bisniswisata. (https://bisniswisata.co.id/yuk-ciptakan-rasa-bahagia-meskiberwisata-virtual-lewat-indonesia-travel-360o-images/, accessed April 7, 2020)

Sanchez-Cabrero, R., Costa-Roman, O., Pericacho-Gomez, F.R., Novillo-Lopez, M.A., Arigita-García A., and Barrientos-Fernandez, A. 2019. "Early virtual reality adopters in Spain: sociodemographic profile and interest in the use of virtual reality as a learning tool," Heliyon (5), pp. 1-28.

Schiopu, A., Hornoiu, R., Padurean, M., and Nica, A. 2021. "Virus tinged? Exploring the facets of virtual reality use in tourism as a result of the COVID-19 pandemic," Telematics and Informatics (60), pp. 101575.

Schumacker, R. E., and Lomax, R. G. 2010. A Beginner's Guide to Structural Equation Modeling. New York: Routledge.

Sheth, J., Newman, B., and Gross, B. 1991. "Why we buy what we buy: a theory of consumption values," Journal of Business Research (22:2), pp. 159-170.

Skanavis, C., and Maria, S. 2011. "International tourism, domestic tourism, and environmental change: environmental education can find the balance," Tourismos: An International Multidisciplinary Journal of Tourism (6:1), pp. 233-249.

Umafagur, F., Sentinuwo, S. R., and Sugiarso, B. A. 2016. "Implementasi virtual Tour Sebagai MEDIA INFORMASI Daerah (Studi Kasus : Kota Manado)," Jurnal Teknik Informatika (9:1), pp. 1-8.

Van der Heijden, H. 2004. "User acceptance of hedonic information systems," MIS Quarterly (28:4), pp. 695-704.

Vishwakarma, P., Mukherjee, S., and Datta, B. 2020. "Travelers' intention to adopt virtual reality: A consumer value perspective," Journal of Destination Marketing \& Management 17, pp. 100456.

Wulur, H., Sentinuwo, S., and Sugiarso, B. 2015. "Aplikasi Virtual Tour Tempat Wisata Alam di Sulawesi Utara,” Jurnal Teknik Informatika (6:1), pp. 1-6. 


\section{Appendix A}

\begin{tabular}{|c|l|}
\hline Code & \\
\hline PE1 & I feel happy exploring virtual tour services \\
\hline PE2 & I feel happy traveling virtually \\
\hline PE3 & I enjoy traveling virtually \\
\hline PE4 & I don't feel bored during a virtual tour \\
\hline ACC1 & Virtual tour services can be enjoyed by society \\
\hline ACC2 & Virtual tour services can be accessed by society \\
\hline ACC3 & Virtual tour services can be accessed anytime and anywhere \\
\hline ACC4 & Access to virtual tour services can be easily obtained \\
\hline EV1 & $\begin{array}{l}\text { Virtual tours provide an experience as if I were actually visiting a tourist } \\
\text { destination }\end{array}$ \\
\hline EV2 & Virtual tours answer my curiosity about a tourist destination \\
\hline EV3 & Virtual tours lift my spirits \\
\hline EV4 & Virtual tours make me feel adventurous \\
\hline TECH1 & I find it easy to access virtual tour services \\
\hline TECH2 & $\begin{array}{l}\text { I find it easy to get information about a tourist destination from a virtual tour } \\
\text { service }\end{array}$ \\
\hline TECH3 & I don't have to spend a lot of effort to join a virtual tour \\
\hline TECH4 & I can easily use the virtual tour \\
\hline FV1 & Virtual tours have a good value for the price \\
\hline FV2 & Virtual tours offer reasonable prices \\
\hline FV3 & Virtual tours have good quality standards \\
\hline FV4 & Virtual tours have consistent quality standards \\
\hline FV5 & Virtual tours are well organized \\
\hline INT1 & I like to find information on the latest technology \\
\hline INT2 & I'm trying to find out about the latest technology trends \\
\hline INT3 & I keep looking for information related to technological developments \\
\hline INT4 & I am interested in virtual tour technology in the world of tourism \\
\hline BIU1 & I plan to use virtual tour services in the future \\
\hline BIU2 & I intend to use virtual tour services in the future \\
\hline BIU3 & I predict that I will use virtual tour services in the future \\
\hline BIU4 & I will recommend virtual tour services to my relatives \\
\hline AU1 & I've used a virtual tour service \\
\hline AU2 & I tend to use virtual tour services if necessary \\
\hline AU3 & I spend a lot of time using virtual tour services \\
\hline AU4 & I often use virtual tour services \\
\hline & \\
\hline & \\
\hline & \\
\hline &
\end{tabular}

\section{How to cite:}

Ramadhanty, A. P., Handayani, P. W., Pinem, A. A., and Hilman, M. H. 2021. "Virtual Tour Actual Usage: The Influence of Perceived Benefits and Sacrifices," Jurnal Sistem Informasi (Journal of Information System) (17:2), pp. 62-76. 